\title{
Function of Metallothionein in Gene Expression and Signal Transduction: Newly Found Protective Role of Metallothionein
}

\author{
Tomoki Kimura $^{a}$ and Norio Itoh ${ }^{*, b}$ \\ ${ }^{a}$ Department of Toxicology, Faculty of Pharmaceutical Sciences, Setsunan University, 45-1 Nagaotoge-cho, Hirakata, Osaka, 573- \\ 0101 Japan and ${ }^{b}$ Department of Toxicology, Graduate School of Pharmaceutical Sciences, Osaka University, 1-6 Yamada-oka, Suita, \\ Osaka, 565-0871 Japan
}

(Received December 29, 2007)

\begin{abstract}
A heavy-metal-binding protein, metallothionein (MT), is induced by heavy metal overload and reactive oxygen species (ROS). The metals and ROS are rendered harmless by binding to MT or by oxidizing MT, respectively. This is a well-known role of MT. MT is also induced by glucocorticoids and cytokines. Induced MT may increase intracellular free zinc and modulate the activity of transcription factors. Changes in MT levels are thought to help in adaptation to changes in environmental conditions. MT modulates inflammatory reactions, including lipopolysaccharide (LPS)-induced expression of cytokines, nitric oxide production from macrophages in response to LPS, and resistance to LPS/D-galactosamine-induced lethality. In this review, we focus on a newly found protective role of MT, which acts mainly via changes in intracellular zinc levels or modulation of gene expression.
\end{abstract}

Key words — metallothionein, zinc, metal-responsive element-binding transcription factor-1, nuclear factor- $\kappa \mathrm{B}$, inflammatory reaction

\section{INTRODUCTION}

Metallothionein (MT) is a low-molecularweight metal-binding protein. ${ }^{1,2)}$ One-third of its amino acid composition is cysteine, and it lacks disulfides, aromatic amino acids, and histidine. In mouse, four $M T$ genes have been cloned, MT-I to $I V . M T-I$ and $I I$ are actively expressed in many cell types in various organs and tissues, as well as in most cultured cells. In contrast, MT-III and $I V$ show a very restricted cell-type-specific expression pattern. ${ }^{3)}$ We focus on MT-I and II. MT has high affinity for heavy metals and is usually saturated with essential metals such as zinc. It has been suggested to maintain zinc homeostasis., ${ }^{45}$ It is known to be induced by heavy metals. ${ }^{1,2)}$ Defense against some heavy metals such as cadmium has been considered to be one of its toxicological roles. Heavy-metal-induced transcriptional activation of

${ }^{*}$ To whom correspondance should be addressed: Department of Toxicology, Graduate School of Pharmaceutical Sciences, Osaka University, 1-6 Yamada-oka, Suita, Osaka, 565-0871 Japan. Tel.: +81-6-6879-8232; Fax: +81-6-6879-8234; E-mail: n-itoh@phs.osaka-u.ac.jp
MT-I and II is mediated by a cis-acting DNA element, metal-responsive element (MRE). ${ }^{6-8)}$ MREbinding transcription factor-1 (MTF-1) is a highly conserved zinc finger transcription factor $(\mathrm{TF})$ that regulates the transcription of target genes, including MT and Zn transporter-1 (ZnT-1), in response to heavy metals. ${ }^{9-12)}$ MT is also induced by reactive oxygen species (ROS), ${ }^{13,14)}$ glucocorticoids (GC), ${ }^{15-17)}$ and some cytokines. ${ }^{18-23)}$ Therefore, the level of MT changes in response to environmental conditions to allow adaptation to the environmental conditions. Some reports show that MT protects cells against factors other than heavy metals. $^{24-27)}$ Here we review; the molecular mechanisms of MT induction, the mechanism of nuclear trafficking of MT, the effect of MT on transcriptional activity, and the physiological role of MT based mainly on our findings.

\section{OVERVIEW OF MT INDUCTION MECHANISMS}

MT is induced by heavy metals and ROS. Loss 
of MTF-1 silences endogenous $M T$ genes, indicating that MTF-1 is required for both the basal and zinc-induced transcription of $M T$ genes. ${ }^{28,29)}$ MTF1 has a metalloregulatory DNA-binding domain composed of six $\mathrm{Cys}_{2} \mathrm{His}_{2}$ zinc fingers. ${ }^{9-11)}$ Deletion mutants missing finger 1 , fingers 5 and 6 , or only finger 6 had severely attenuated metal-induced binding to mouse MT-I promoter. ${ }^{30)}$ A study of point mutations of zinc fingers showed that the six fingers are not functionally equivalent in zinc response. ${ }^{31)}$ A potential role in MTF-1 zinc sensing contributed by an unusual (non-canonical) peptide RGEYT linker connecting the two N-terminal zinc fingers was reported recently. ${ }^{32)}$ MTF-1 is also the key factor in response to cadmium and ROS. But the exact mechanisms of MT induction are not clear.

Activation of MTF-1 depends only on zinc in a cell-free system; e.g., addition of cadmium to recombinant MTF-1 or cell extract does not activate MTF-1 in electrophoretic mobility shift assay, as shown in a cell-free, MTF-1-dependent transcription system. ${ }^{33)}$ Transcriptional induction by cadmium, copper, or $\mathrm{H}_{2} \mathrm{O}_{2}$ additionally requires the presence of zinc-saturated MT (Zn-MT). This induction is explained by the preferential binding of cadmium or copper to MT or its oxidation by $\mathrm{H}_{2} \mathrm{O}_{2}$; the concomitant release of zinc in turn leads to the activation of MTF-1 (Fig. 1). But this ex- planation contradicts the result that approximately $100 \mu \mathrm{M}$ zinc is needed for activation of MTF-1 in cultured cells but only $20 \mu \mathrm{M}$ of cadmium. Twenty $\mu \mathrm{M}$ cadmium might not release the same amount of zinc as $100 \mu \mathrm{M}$ zinc. The upstream stimulatory factor (USF) family and the antioxidant response element (ARE), which overlaps the USF-binding site (USF/ARE), are involved in MT induction by $\mathrm{H}_{2} \mathrm{O}_{2}$ and cadmium. ${ }^{14)}$ A cysteine-rich cluster, from the $\mathrm{C}$-terminus to a serine/threonine-rich transcriptional activation domain, was specifically required for MTF-1 to activate transcription by heavy metals. ${ }^{34)}$ Phosphorylation might be involved in the activation of MTF-1 in response to heavy metals. ${ }^{35-37)}$

Molecular mechanisms of MT induction by cadmium and ROS are still unclear. MT was induced under hypoxia, and the induction was mediated by cooperative interactions between MTF-1 and hypoxia-inducible factor- $1 \alpha .{ }^{38-40)}$ MT expression was suppressed in primary human hepatocellular carcinoma and was mediated through inactivation of CCAAT/enhancer-binding protein $\alpha$ by the phosphatidylinositol 3-kinase signaling cascade. ${ }^{41)}$ Sp1, a TF, might inhibit MT expression via competition with MTF-1-MRE binding. ${ }^{42)}$ The mechanism of MTF-1-mediated MT expression might be complicated.

MT synthesis is induced in response to



Fig. 1. Proposed Molecular Mechanisms in Mouse MT-I Gene Transcription

In response to heavy metals or ROS, zinc is released from Zn-MT or Zn-binding protein(s). The released zinc and other zinc brought in by ZIP family zinc importers activates MTF-1-mediated MT-I gene transcription. Phosphorylation of MTF-1 might be involved in its activation. In response to IL-6, activated STAT3 and GC-bound GR synergistically activate MT-I gene transcription. Sp1 and USF-1/USF-2 constitutively bind to these binding elements. 
inflammation-producing compounds..$^{20,43-45)}$ We revealed that the MT-inducing factor is interleukin (IL)-6. ${ }^{22}$ We detected the MT-inducing factor of cultured hepatoma cells in the serum of lipopolysaccharide (LPS)-treated mice, and found that the presence of GC at the physiological level was necessary for the factor's MT-inducing activity. The activity was inhibited by the addition or preadministration of anti-IL-6 antibody in cultured cells and experimental animals. ${ }^{46)}$ Studies at the promoter gene level showed that both the type 2 IL-6-responsive element and the GC-responsive element are required for synergistic activation by IL-6 and GC (Fig. 1). ${ }^{22)}$ This synergistic activation required not only the binding of signal transducer and activator 3 (STAT3) and GC receptor (GR) to their responsive elements, but also probably the interaction of STAT3 and GR with each other. ${ }^{47)}$ MT induction by some heavy metals $\left(\mathrm{Ce}^{3+}, \mathrm{V}^{5+}, \mathrm{Mn}^{2+}\right)$ was completely or partially mediated by IL-6. ${ }^{48-50)}$ IL-6 is the acute-phase protein-inducing factor, and MT is a kind of acute-phase protein. Other cytokines-IL$1,{ }^{19)}$ tumor necrosis factor (TNF)- $\alpha$ and interferon$\gamma,{ }^{18,23)}$ and $\mathrm{GC}^{15-17)}$ —also induce MT expression. These results suggest that MT modulates the inflammatory response. The putative role of MT in the acute-phase response is discussed below.

\section{NUCLEAR TRAFFICKING OF METALLOTHIONEIN}

MT was first reported as a heavy-metal-binding protein in the cytosolic fraction. ${ }^{51)}$ It was subsequently found in the nucleus. ${ }^{52-57)}$ Localization of MT in nuclei was observed in growing primary-cultured hepatocytes. ${ }^{54)}$ Its translocation in digitonin-permeabilized BALB/c3T3 cells depended on the presence of ATP and cytosol factor(s) in a similar manner as for classical nuclear localization signal (NLS)-mediated nuclear translocation, even though there is no NLS in MT and the cytosolic factor is different. ${ }^{58)}$ MT was localized in the nucleus in response to the generation of a feeble ROS at the $\mathrm{S}$ phase. ${ }^{59)}$ Fluorescencelabeled MT-II diffused into the nucleus of SCC25 cells, where it was selectively and actively retained by nuclear binding factors. ${ }^{60)}$ However, the detailed mechanism of the nuclear localization of MT is still unknown. These observations suggest that nuclear MT protects nuclei from oxidation occurring with progression of the cell cycle. On the other hand, some TFs contain zinc finger domains for interaction with their cognate DNA sequences. The zinc is the essential factor for the DNA-binding, because removing zinc ions complexed in these zinc fingers abrogates DNA-binding and transcriptional activity. Estrogen receptor (ER) in metal-depleted nuclear extracts exhibits reduced DNA-binding. ${ }^{61)}$ Its binding can be restored with Zn-MT. Hence, apothionine (apo-MT) inhibits DNA-binding by abstracting zinc from functional ER.

\section{FUNCTION OF MT IN MODIFICATION OF TRANSCRIPTIONAL ACTIVITY}

We reported that MTF-1 was activated during endotoxemia, and that this activation was mediated by an increase in Zn-MT (Fig. 2). ${ }^{62)}$ The intracellular free zinc concentration is tightly regulated. Transcription mediated by Zur and ZntR, Zn-responsive TFs of Escherichia coli (E. coli), responded to around $10^{-15} \mathrm{M}$ free zinc. ${ }^{63)}$ The maximum volume of a typical $E$. coli cell in exponential phase is about $10^{-15}$ liter. The lowest possible concentration of free zinc, corresponding to one zinc atom per cell, would be $1 \times 10^{-9} \mathrm{M}$. Thus, the concentration is $\ll 1$ labile zinc ion per $E$. coli cell. In eukaryotic cell, labile zinc concentration is estimated $\gg 1$ ion/cell. ${ }^{64)}$ The increase in Zn-MT must increase the intracellular available zinc pool because $\mathrm{Zn}-\mathrm{MT}$ is equilibrium to free $\mathrm{Zn}$ and apoMT (Fig. 3). On the other hand, increased MT expression maintains the intracellular zinc level under limited availability of zinc from the environment. MT-conferred MTF-1 activation may be mediated through an increase of the available zinc pool. ${ }^{65}$ ) Because MT, despite its high metal binding constant $\left(\mathrm{K}_{\mathrm{Zn}}=3.2 \times 10^{13} \mathrm{M}^{-1}\right.$ at $\left.\mathrm{pH} 7.4\right)$, can transfer zinc to the apoforms of zinc enzymes that have inherently lower stability constants. ${ }^{66)}$ Several results indicate that MT acts as a zinc chelator or donor for zinc-finger-type TFs, including ER, Sp1, and TF IIIA. ${ }^{61,67-69)}$

MT activates the DNA-binding activity of nuclear factor $-\kappa \mathrm{B}(\mathrm{NF}-\kappa \mathrm{B})$, and causes NF- $\kappa \mathrm{B}-$ mediated transactivation (Fig. 2). ${ }^{70,71)}$ Activity of the human cytomegalovirus major immediate-early promoter was regulated by intracellular zinc levels. Overexpression of MT upregulates the DNA binding of NF- $\kappa \mathrm{B}$ and thus NF- $\kappa \mathrm{B}$-induced activation 


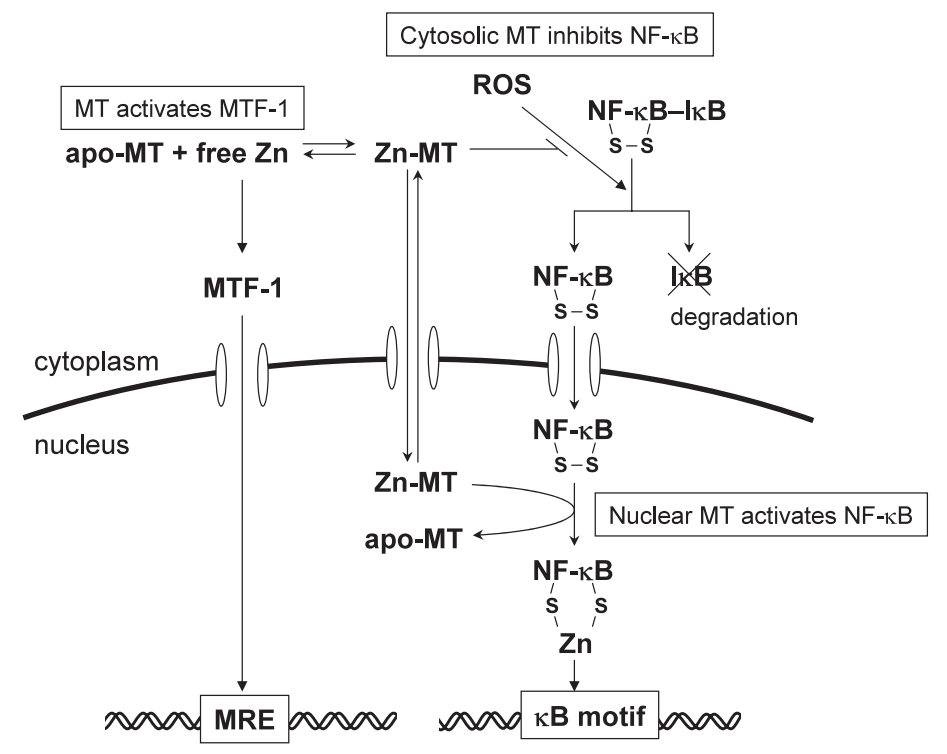

Fig. 2. Proposed Mechanisms of MT-mediated Modification of MTF-1 and NF- $\kappa$ B activities

MTF-1 activation during endotoxemia is mediated by an increase in Zn-MT. NF- $\kappa$ B is activated by nuclear Zn-MT. Disulfides in NF- $\kappa$ B are reduced by Zn-MT. Zn bound to MT is transferred to cysteine residues in NF- $\kappa$ B. In cytosol, MT scavenges radicals and inhibits ROS-mediated NF- $\kappa$ B activation.

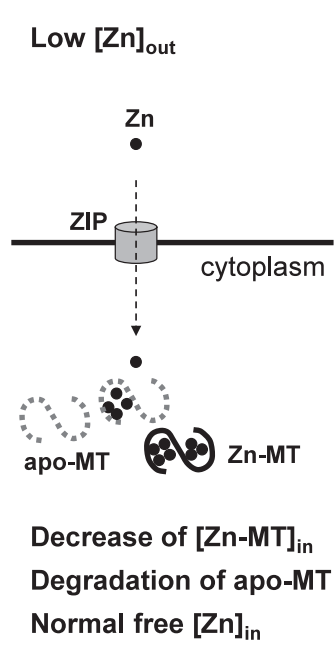

Normal condition

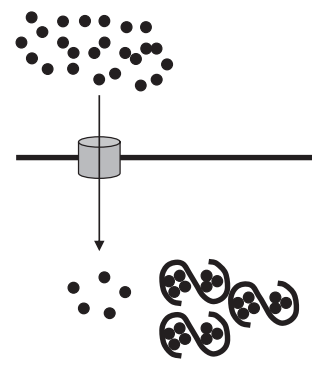

Degradation of apo-MT

Normal free $[\mathrm{Zn}]_{\text {in }}$
High $[\mathrm{MT}]_{\text {in }}$

Sufficient Zn supply

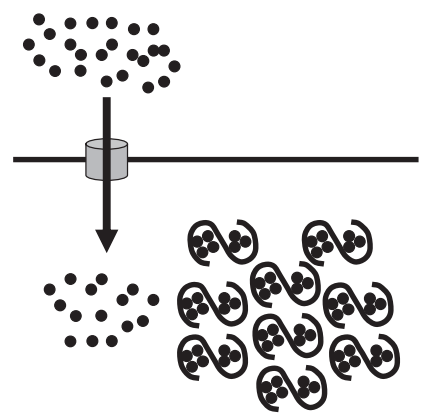

Increase of free $[\mathrm{Zn}]_{\text {in }}$ Increase of MTF-1 activity

Fig. 3. Proposed Mechanisms of MT-mediated Control of Intracellular Zinc Concentration

When extracellular zinc is restricted, produced MT incorporates zinc. If the incorporated zinc is not sufficient to saturate apo-MT, apo-MT is degraded. During endotoxemia, MT expression is induced and Zn-MT is increased. When zinc supply is sufficient, the intracellular free zinc concentration is increased in response to increase in Zn-MT.

of transcription. NF- $\kappa \mathrm{B}$ is not a zinc-finger-type $\mathrm{TF}$, but zinc is necessary for its activation. In the nucleus, disulfides in NF- $\kappa \mathrm{B}$ are reduced to thiol residues by thioredoxin. ${ }^{72)}$ The cysteine residues in $\mathrm{NF}-\kappa \mathrm{B}$ must free in order to bind zinc. ${ }^{73)} \mathrm{A}$ specific interaction between MT and the p50 subunit of NF- $\kappa \mathrm{B}$ was reported. ${ }^{74)}$ MT may be easily oxidized and so provide zinc immediately. MT acts as a redox factor in the same way as thioredoxin and thus donates zinc. LPS-induced expres- sion of TNF- $\alpha$, IL- $1 \alpha$, and IL-6 mRNAs was decreased in MT-knockout $\left(\mathrm{MT}^{-/-}\right)$peritoneal exudate macrophages. These decreased expressions caused inadequate activation of NF- $\kappa \mathrm{B} .{ }^{75)}$ Zinc-induced expression of macrophage colonystimulating factor in MC3T3-E1 and L929 cells required MT-mediated NF- $\kappa$ B activation. ${ }^{76)}$ On the other hand, NF- $\kappa \mathrm{B}$ is a redox-regulated TF, and MT may control intracellular redox status. Cytosolic MT may act as a negative regulator of NF- $\kappa \mathrm{B}$ ac- 
tivity. ${ }^{77)}$ Whether MT activates or inhibits NF- $\kappa$ B might depend on the cell type and the stage in the cell cycle.

\section{PHYSIOLOGICAL ROLE OF MT AND ITS PUTATIVE MECHANISM}

As mentioned above, MT aids in maintaining zinc homeostasis and protects against toxicity induced by excess zinc and other heavy metals. ${ }^{1,2,4,5)}$ The physiological role of MT has been studied in $\mathrm{MT}^{-/-}$mice. Independent researchers found that MT modulates the intracellular zinc level (Fig. 3) and gene expression, cell function, and acute-phase response. A number of MT-regulated genes were reported. ${ }^{78-80)}$ Some could be regulated by the MTmediated modification of MTF- 1 and NF- $\kappa$ B activity, as shown in Fig. 2. Some tissue-specific regulation was observed. For example, glucose-6phosphatase expression in $\mathrm{MT}^{-/-}$mice was downregulated in liver and upregulated in kidney. ${ }^{80)}$ The regulation mechanism is unknown. Further characterization of these genes will determine whether their expressions are primary or secondary effects of an MT deficiency.

MT modulates cell functions. Reduced bactericidal activity was observed in $\mathrm{MT}^{-/-}$peritoneal exudate macrophages. ${ }^{81)}$ Macrophages play important roles in the immune response and in inflammation. They produce nitric oxide (NO) in response to microbial infection as a bactericidal factor. Levels of expression of inducible NO synthase (iNOS) mRNA and production of iNOS protein in response to LPS stimulation were similar in $\mathrm{MT}^{+/+}$ and $\mathrm{MT}^{-/-}$cells. The reduced production of NO in $\mathrm{MT}^{-/-}$macrophages is due mainly to reduced activity of iNOS. Thiol-dependent NO stores increased the tissue NO level during renal ischemia. ${ }^{82)} \mathrm{NO}$ can react with the SH group of MT in vitro, leading to the release of metals from MT. ${ }^{83)}$ The MT molecule has the potential to trap NO, and might modulate NO-mediated signaling. Zinc homeostasis might be partially regulated by interaction of $\mathrm{NO}$ with MT. ${ }^{84)}$

The specific role of MT in liver regeneration after partial hepatectomy, chemical injury, and fibrosis was reported. ${ }^{26)}$ Defective liver regeneration after injury in $\mathrm{MT}^{-1-}$ mice was observed. On the other hand, MT might be involved in cell proliferation because zinc modulates cell proliferation (Fig. 4). Zinc inhibits protein tyrosine phosphatase



Fig. 4. Relationship between Zinc and ERK Pathway IGF-1 receptor (IGF-1R) is phosphorylated in response to binding of IGF-1. IGF-1 signaling is inhibited by a phosphatase, PTP 1B. PTP $1 \mathrm{~B}$ activity is inhibited by zinc. ZnT-1, zinc efflux transporter, activates Raf-1. The activation by ZnT-1 is inhibited by zinc treatment. MTF-1, which regulates $\mathrm{ZnT}-1$ expression, activates the ERK pathway.

activity in insulin/insulin-like growth factor (IGF)1 signaling. ${ }^{85)} \mathrm{ZnT}-1$, a zinc exporter whose gene is one of the targets of MTF-1, modulates the activity of the Ras-extracellular-signal-regulated kinase (ERK) cascade. ${ }^{86,87)}$ ZnT-1 binds to the aminoterminal regulatory portion of Raf-1, an upstream kinase in the ERK cascade, and promotes the enzymatic activity. Zn inhibits Raf-1 binding to ZnT1. Raf-1 plays an important role in signal transduction and cell proliferation. We reported that inhibition of MTF-1 by dominant-negative MTF- ${ }^{88)}$ and MTF-1 siRNA decreased epidermal growth factordependent ERK phosphorylation in primary hepatocytes. ${ }^{89)}$ Phosphorylation of ERK has been shown to be essential for cell proliferation. MTF-1 mediates MT production, and MT might modulate MTF-1 activity. ${ }^{33,62)}$ This signaling cycle might modulate cell function.

MT modulates inflammation. $\mathrm{MT}^{-/-}$mice are more sensitive to LPS/D-galactosamine (GalN)induced lethality than are $\mathrm{MT}^{+/+}$mice. ${ }^{24,25)}$ The levels of vital mediators-TNF, NO, and plateletactivating factor-were similar in $\mathrm{MT}^{+/+}$and $\mathrm{MT}^{-/-}$mice, whereas the mRNA levels of the protective protein, $\alpha_{1}$-acid glycoprotein, in response to $\mathrm{LPS} / \mathrm{GalN}$ were lower in $\mathrm{MT}^{-/-}$mice. In this LPS/GalN model, zinc preadministration protects against lethality. ${ }^{90)}$ The effects of an MT deficiency might be dysfunction of zinc-mediated protective gene expression. MT also protects against coagu- 
latory and fibrinolytic disturbance and multiple organ damage induced by LPS, at least partly, via inhibition of the expression of proinflammatory proteins. $^{27)}$

\section{CONCLUSIONS}

We reviewed the physiological role of MT and showed some roles of MT with their mechanisms. Most of the functions can be explain by changes in intracellular zinc concentration or modulation of gene expression. MT is induced by exposure to xenobiotics and changes in environment. Induced MT modulates intracellular zinc concentration or gene expression and protects cells from the xenobiotics and changes in environment. MT has many other functions as well; for example, it protects against carcinogenesis. ${ }^{91)}$ These functions might also be based on changes in intracellular zinc level or modulation of gene expression. A rapid increase in intracellular zinc concentration is important for cell signaling in mast cells. ${ }^{92)}$ MT might be involved in a lot of cell signaling systems. Further study of MT will reveal the exact molecular mechanisms.

Acknowledgements We thank our laboratory staff for their helpful advice. This research was partially supported by the Japan Society for the Promotion of Science (Grant-in-Aid for Scientific Research).

\section{REFERENCES}

1) Hamer, D. H. (1986) Metallothionein. Annu. Rev. Biochem., 55, 913-951.

2) Kagi, J. H. and Schaffer, A. (1988) Biochemistry of metallothionein. Biochemistry, 27, 8509-8515.

3) Ghoshal, K. and Jacob, S. T. (2001) Regulation of metallothionein gene expression. Prog. Nucleic Acid Res. Mol. Biol., 66, 357-384.

4) Dalton, T., Fu, K., Palmiter, R. D. and Andrews, G. K. (1996) Transgenic mice that overexpress metallothionein-I resist dietary zinc deficiency. $J$. Nutr., 126, 825-833.

5) Kelly, E. J., Quaife, C. J., Froelick, G. J. and Palmiter, R. D. (1996) Metallothionein I and II protect against zinc deficiency and zinc toxicity in mice. J. Nutr., 126, 1782-1790.

6) Searle, P. F., Stuart, G. W. and Palmiter, R. D. (1985)
Building a metal-responsive promoter with synthetic regulatory elements. Mol. Cell. Biol., 5, 1480-1489.

7) Stuart, G. W., Searle, P. F. and Palmiter, R. D. (1985) Identification of multiple metal regulatory elements in mouse metallothionein-I promoter by assaying synthetic sequences. Nature, 317, 828-831.

8) Culotta, V. C. and Hamer, D. H. (1989) Fine mapping of a mouse metallothionein gene metal response element. Mol. Cell. Biol., 9, 1376-1380.

9) Radtke, F., Heuchel, R., Georgiev, O., Hergersberg, M., Gariglio, M., Dembic, Z. and Schaffner, W. (1993) Cloned transcription factor MTF-1 activates the mouse metallothionein I promoter. $E M B O J_{.}, \mathbf{1 2}$, $1355-1362$.

10) Brugnera, E., Georgiev, O., Radtke, F., Heuchel, R., Baker, E., Sutherland, G. R. and Schaffner, W. (1994) Cloning, chromosomal mapping and characterization of the human metal-regulatory transcription factor MTF-1. Nucleic Acids Res., 22, $3167-$ 3173.

11) Otsuka, F., Iwamatsu, A., Suzuki, K., Ohsawa, M., Hamer, D. H. and Koizumi, S. (1994) Purification and characterization of a protein that binds to metal responsive elements of the human metallothionein IIA gene. J. Biol. Chem., 269, 23700-23707.

12) Laity, J. H. and Andrews, G. K. (2007) Understanding the mechanisms of zinc-sensing by metal-response element binding transcription factor1 (MTF-1). Arch. Biochem. Biophys., 463, 201-210.

13) Bauman, J. W., Liu, J., Liu, Y. P. and Klaassen, C. D. (1991) Increase in metallothionein produced by chemicals that induce oxidative stress. Toxicol. Appl. Pharmacol., 110, 347-354.

14) Andrews, G. K. (2000) Regulation of metallothionein gene expression by oxidative stress and metal ions. Biochem. Pharmacol., 59, 95-104.

15) Hager, L. J. and Palmiter, R. D. (1981) Transcriptional regulation of mouse liver metallothionein-I gene by glucocorticoids. Nature, 291, 340-342.

16) Mayo, K. E. and Palmiter, R. D. (1981) Glucocorticoid regulation of metallothionein-I mRNA synthesis in cultured mouse cells. J. Biol. Chem., 256, 2621-2624.

17) Ghoshal, K., Wang, Y., Sheridan, J. F. and Jacob, S. T. (1998) Metallothionein induction in response to restraint stress. Transcriptional control, adaptation to stress, and role of glucocorticoid. J. Biol. Chem., 273, 27904-27910.

18) Friedman, R. L. and Stark, G. R. (1985) alphaInterferon-induced transcription of HLA and metallothionein genes containing homologous upstream sequences. Nature, 314, 637-639.

19) Cousins, R. J. and Leinart, A. S. (1988) Tissue- 
specific regulation of zinc metabolism and metallothionein genes by interleukin 1. FASEB J., 2 , 2884-2890.

20) De, S. K., McMaster, M. T. and Andrews, G. K. (1990) Endotoxin induction of murine metallothionein gene expression. J. Biol. Chem., 265, 1526715274.

21) Schroeder, J. J. and Cousins, R. J. (1990) Interleukin 6 regulates metallothionein gene expression and zinc metabolism in hepatocyte monolayer cultures. Proc. Natl. Acad. Sci. U.S.A., 87, 3137-3141.

22) Kasutani, K., Itoh, N., Kanekiyo, M., Muto, N. and Tanaka, K. (1998) Requirement for cooperative interaction of interleukin- 6 responsive element type 2 and glucocorticoid responsive element in the synergistic activation of mouse metallothionein-I gene by interleukin-6 and glucocorticoid. Toxicol. Appl. Pharmacol., 151, 143-151.

23) Guevara-Ortiz, J. M., Omar-Castellanos, V., LeonChavez, B. A., Achanzar, W. E. and Brambila, E. (2005) Interferon alpha induction of metallothionein in rat liver is not linked to interleukin-1, interleukin6, or tumor necrosis factor alpha. Exp. Mol. Pathol., 79, 33-38.

24) Kimura, T., Koujitani, T., Itoh, N., Takehara, M., Oguro, I., Ishizaki, J., Nakanishi, T. and Tanaka, K. (2001) Metallothionein-null mice are sensitive to endotoxin/D-galactosamine-induced hepatotoxicity. J. Health Sci., 47, 310-313.

25) Kimura, T., Itoh, N., Takehara, M., Oguro, I., Ishizaki, J. I., Nakanishi, T. and Tanaka, K. (2001) Sensitivity of metallothionein-null mice to LPS/Dgalactosamine-induced lethality. Biochem. Biophys. Res. Commun., 280, 358-362.

26) Cherian, M. G. and Kang, Y. J. (2006) Metallothionein and liver cell regeneration. Exp. Biol. Med. (Maywood), 231, 138-144.

27) Inoue, K., Takano, H., Shimada, A., Wada, E., Yanagisawa, R., Sakurai, M., Satoh, M. and Yoshikawa, T. (2006) Role of metallothionein in coagulatory disturbance and systemic inflammation induced by lipopolysaccharide in mice. FASEB J., 20, 533-535.

28) Heuchel, R., Radtke, F., Georgiev, O., Stark, G., Aguet, M. and Schaffner, W. (1994) The transcription factor MTF-1 is essential for basal and heavy metal-induced metallothionein gene expression. EMBO J., 13, 2870-2875.

29) Gunes, C., Heuchel, R., Georgiev, O., Muller, K. H., Lichtlen, P., Bluthmann, H., Marino, S., Aguzzi, A. and Schaffner, W. (1998) Embryonic lethality and liver degeneration in mice lacking the metalresponsive transcriptional activator MTF-1. EMBO

\section{J., 17, 2846-2854.}

30) Jiang, H., Daniels, P. J. and Andrews, G. K. (2003) Putative zinc-sensing zinc fingers of metal-response element-binding transcription factor- 1 stabilize a metal-dependent chromatin complex on the endogenous metallothionein-I promoter. J. Biol. Chem., 278, 30394-30402.

31) Koizumi, S., Suzuki, K., Ogra, Y., Gong, P. and Otuska, F. (2000) Roles of zinc fingers and other regions of the transcription factor human MTF-1 in zinc-regulated DNA binding. J. Cell. Physiol., 185, 464-472.

32) Li, Y., Kimura, T., Laity, J. H. and Andrews, G. K. (2006) The zinc-sensing mechanism of mouse MTF1 involves linker peptides between the zinc fingers. Mol. Cell. Biol., 26, 5580-5587.

33) Zhang, B., Georgiev, O., Hagmann, M., Gunes, C., Cramer, M., Faller, P., Vasak, M. and Schaffner, W. (2003) Activity of metal-responsive transcription factor 1 by toxic heavy metals and $\mathrm{H}_{2} \mathrm{O}_{2}$ in vitro is modulated by metallothionein. Mol. Cell. Biol., 23, 8471-8485.

34) Chen, X., Zhang, B., Harmon, P. M., Schaffner, W., Peterson, D. O. and Giedroc, D. P. (2004) A novel cysteine cluster in human metal-responsive transcription factor 1 is required for heavy metalinduced transcriptional activation in vivo. J. Biol. Chem., 279, 4515-4522.

35) LaRochelle, O., Gagne, V., Charron, J., Soh, J. W. and Seguin, C. (2001) Phosphorylation is involved in the activation of metal-regulatory transcription factor 1 in response to metal ions. J. Biol. Chem., 276, 41879-41888.

36) Saydam, N., Adams, T. K., Steiner, F., Schaffner, W. and Freedman, J. H. (2002) Regulation of metallothionein transcription by the metal-responsive transcription factor MTF-1: identification of signal transduction cascades that control metal-inducible transcription. J. Biol. Chem., 277, 20438-20445.

37) Jiang, H., Fu, K. and Andrews, G. K. (2004) Geneand cell-type-specific effects of signal transduction cascades on metal-regulated gene transcription appear to be independent of changes in the phosphorylation of metal-response-element-binding transcription factor-1. Biochem. J., 382, 33-41.

38) Murphy, B. J., Andrews, G. K., Bittel, D., Discher, D. J., McCue, J., Green, C. J., Yanovsky, M., Giaccia, A., Sutherland, R. M., Laderoute, K. R. and Webster, K. A. (1999) Activation of metallothionein gene expression by hypoxia involves metal response elements and metal transcription factor-1. Cancer Res., 59, 1315-1322.

39) Murphy, B. J. (2004) Regulation of malignant pro- 
gression by the hypoxia-sensitive transcription factors HIF-1alpha and MTF-1. Comp. Biochem. Physiol. B, Biochem. Mol. Biol., 139, 495-507.

40) Murphy, B. J., Sato, B. G., Dalton, T. P. and Laderoute, K. R. (2005) The metal-responsive transcription factor-1 contributes to HIF-1 activation during hypoxic stress. Biochem. Biophys. Res. Commun., 337, 860-867.

41) Datta, J., Majumder, S., Kutay, H., Motiwala, T., Frankel, W., Costa, R., Cha, H. C., MacDougald, O. A., Jacob, S. T. and Ghoshal, K. (2007) Metallothionein expression is suppressed in primary human hepatocellular carcinomas and is mediated through inactivation of CCAAT/enhancer binding protein alpha by phosphatidylinositol 3-kinase signaling cascade. Cancer Res., 67, 2736-2746.

42) Ogra, Y., Suzuki, K., Gong, P., Otsuka, F. and Koizumi, S. (2001) Negative regulatory role of $\mathrm{Sp} 1$ in metal responsive element-mediated transcriptional activation. J. Biol. Chem., 276, 16534-16539.

43) Min, K. S., Terano, Y., Onosaka, S. and Tanaka, K. (1991) Induction of hepatic metallothionein by nonmetallic compounds associated with acute-phase response in inflammation. Toxicol. Appl. Pharmacol., 111, 152-162.

44) Min, K. S., Terano, Y., Onosaka, S. and Tanaka, K. (1992) Induction of metallothionein synthesis by menadione or carbon tetrachloride is independent of free radical production. Toxicol. Appl. Pharmacol., 113, 74-79.

45) Itoh, N., Okamoto, H., Ohta, M., Hori, T., Min, K. S., Onosaka, S., Nakanishi, H., Okabe, M., Muto, N. and Tanaka, K. (1994) n-hexane-induced synthesis of hepatic metallothionein is mediated by IL-6 in mouse. Toxicol. Appl. Pharmacol., 124, 257-261.

46) Itoh, N., Kasutani, K., Muto, N., Otaki, N., Kimura, M. and Tanaka, K. (1996) Blocking effect of anti-mouse interleukin-6 monoclonal antibody and glucocorticoid receptor antagonist, RU38486, on metallothionein-inducing activity of serum from lipopolysaccharide-treated mice. Toxicology, 112, 29-36.

47) Lee, D. K., Carrasco, J., Hidalgo, J. and Andrews, G. K. (1999) Identification of a signal transducer and activator of transcription (STAT) binding site in the mouse metallothionein-I promoter involved in interleukin-6-induced gene expression. Biochem. J., 337, 59-65.

48) Kobayashi, K., Shida, R., Hasegawa, T., Satoh, M., Seko, Y., Tohyama, C., Kuroda, J., Shibata, N., Imura, N. and Himeno, S. (2005) Induction of hepatic metallothionein by trivalent cerium: role of interleukin 6. Biol. Pharm. Bull., 28, 1859-1863.
49) Kobayashi, K., Himeno, S., Satoh, M., Kuroda, J., Shibata, N., Seko, Y. and Hasegawa, T. (2006) Pentavalent vanadium induces hepatic metallothionein through interleukin-6-dependent and -independent mechanisms. Toxicology, 228, 162-170.

50) Kobayashi, K., Kuroda, J., Shibata, N., Hasegawa, T., Seko, Y., Satoh, M., Tohyama, C., Takano, H., Imura, N., Sakabe, K., Fujishiro, H. and Himeno, S. (2007) Induction of metallothionein by manganese is completely dependent on interleukin-6 production. J. Pharmacol. Exp. Ther, 320, 721-727.

51) Kagi, J. H. and Valee, B. L. (1960) Metallothionein: a cadmium- and zinc-containing protein from equine renal cortex. J. Biol. Chem., 235, 3460-3465.

52) Danielson, K. G., Ohi, S. and Huang, P. C. (1982) Immunochemical detection of metallothionein in specific epithelial cells of rat organs. Proc. Natl. Acad. Sci. U.S.A., 79, 2301-2304.

53) Banerjee, D., Onosaka, S. and Cherian, M. G. (1982) Immunohistochemical localization of metallothionein in cell nucleus and cytoplasm of rat liver and kidney. Toxicology, 24, 95-105.

54) Tsujikawa, K., Imai, T., Kakutani, M., Kayamori, Y., Mimura, T., Otaki, N., Kimura, M., Fukuyama, R. and Shimizu, N. (1991) Localization of metallothionein in nuclei of growing primary cultured adult rat hepatocytes. FEBS Lett., 283, 239-242.

55) Woo, E. S., Kondo, Y., Watkins, S. C., Hoyt, D. G. and Lazo, J. S. (1996) Nucleophilic distribution of metallothionein in human tumor cells. Exp. Cell Res., 224, 365-371.

56) Cherian, M. G. and Apostolova, M. D. (2000) Nuclear localization of metallothionein during cell proliferation and differentiation. Cell. Mol. Biol. (Noisy-le-grand), 46, 347-356.

57) Ogra, Y. and Suzuki, K. T. (2000) Nuclear trafficking of metallothionein: possible mechanisms and current knowledge. Cell. Mol. Biol. (Noisy-legrand), 46, 357-365.

58) Nagano, T., Itoh, N., Ebisutani, C., Takatani, T., Miyoshi, T., Nakanishi, T. and Tanaka, K. (2000) The transport mechanism of metallothionein is different from that of classical NLS-bearing protein. $J$. Cell. Physiol., 185, 440-446.

59) Takahashi, Y., Ogra, Y. and Suzuki, K. T. (2005) Nuclear trafficking of metallothionein requires oxidation of a cytosolic partner. J. Cell. Physiol., 202, 563-569.

60) Woo, E. S., Dellapiazza, D., Wang, A. S. and Lazo, J. S. (2000) Energy-dependent nuclear binding dictates metallothionein localization. J. Cell. Physiol., 182, 69-76.

61) Cano-Gauci, D. F. and Sarkar, B. (1996) Reversible 
zinc exchange between metallothionein and the estrogen receptor zinc finger. FEBS Lett., 386, 1-4.

62) Kimura, T., Itoh, N., Takehara, M., Oguro, I., Ishizaki, J., Nakanishi, T. and Tanaka, K. (2002) MRE-binding transcription factor-1 is activated during endotoxemia: a central role for metallothionein. Toxicol. Lett., 129, 77-84.

63) Outten, C. E. and O'Halloran, T. V. (2001) Femtomolar sensitivity of metalloregulatory proteins controlling zinc homeostasis. Science, 292, 2488-2492.

64) Wang, Z., Feng, L. S., Matskevich, V., Venkataraman, K., Parasuram, P. and Laity, J. H. (2006) Solution structure of a Zap1 zinc-responsive domain provides insights into metalloregulatory transcriptional repression in Saccharomyces cerevisiae. J. Mol. Biol., 357, 1167-1183.

65) Suhy, D. A., Simon, K. D., Linzer, D. I. and O'Halloran, T. V. (1999) Metallothionein is part of a zinc-scavenging mechanism for cell survival under conditions of extreme zinc deprivation. J. Biol. Chem., 274, 9183-9192.

66) Jacob, C., Maret, W. and Vallee, B. L. (1998) Control of zinc transfer between thionein, metallothionein, and zinc proteins. Proc. Natl. Acad. Sci. U.S.A., 95, 3489-3494.

67) Zeng, J., Heuchel, R., Schaffner, W. and Kagi, J. H. (1991) Thionein (apometallothionein) can modulate DNA binding and transcription activation by zinc finger containing factor Sp1. FEBS Lett., 279, 310-312.

68) Zeng, J., Vallee, B. L. and Kagi, J. H. (1991) Zinc transfer from transcription factor IIIA fingers to thionein clusters. Proc. Natl. Acad. Sci. U.S.A., 88, 9984-9988.

69) Roesijadi, G., Bogumil, R., Vasak, M. and Kagi, J. H. (1998) Modulation of DNA binding of a tramtrack zinc finger peptide by the metallothioneinthionein conjugate pair. J. Biol. Chem., 273, 1742517432.

70) Kanekiyo, M., Itoh, N., Mano, M., Kawasaki, A., Tanaka, J., Muto, N. and Tanaka, K. (2000) Cellular zinc status regulates cytomegalovirus major immediate-early promoter. Antiviral Res., 47, 207214.

71) Kanekiyo, M., Itoh, N., Kawasaki, A., Tanaka, J., Nakanishi, T. and Tanaka, K. (2001) Zincinduced activation of the human cytomegalovirus major immediate-early promoter is mediated by metallothionein and nuclear factor-kappaB. Toxicol. Appl. Pharmacol., 173, 146-153.

72) Hirota, K., Murata, M., Sachi, Y., Nakamura, H., Takeuchi, J., Mori, K. and Yodoi, J. (1999) Distinct roles of thioredoxin in the cytoplasm and in the nu- cleus. A two-step mechanism of redox regulation of transcription factor NF-kappaB. J. Biol. Chem., 274, 27891-27897.

73) Yang, J. P., Merin, J. P., Nakano, T., Kato, T., Kitade, Y. and Okamoto, T. (1995) Inhibition of the DNAbinding activity of NF-kappa B by gold compounds in vitro. FEBS Lett., 361, 89-96.

74) Abdel-Mageed, A. B. and Agrawal, K. C. (1998) Activation of nuclear factor kappaB: potential role in metallothionein-mediated mitogenic response. Cancer Res., 58, 2335-2338.

75) Kanekiyo, M., Itoh, N., Kawasaki, A., Matsuyama, A., Matsuda, K., Nakanishi, T. and Tanaka, K. (2002) Metallothionein modulates lipopolysaccharidestimulated tumour necrosis factor expression in mouse peritoneal macrophages. Biochem. J., 361, 363-369.

76) Kanekiyo, M., Itoh, N., Kawasaki, A., Matsuda, K., Nakanishi, T. and Tanaka, K. (2002) Metallothionein is required for zinc-induced expression of the macrophage colony stimulating factor gene. J. Cell. Biochem., 86, 145-153.

77) Sakurai, A., Hara, S., Okano, N., Kondo, Y., Inoue, J. and Imura, N. (1999) Regulatory role of metallothionein in NF-kappaB activation. FEBS Lett., 455, 55-58.

78) Kimura, T., Oguro, I., Kohroki, J., Takehara, M., Itoh, N., Nakanishi, T. and Tanaka, K. (2000) Metallothionein-null mice express altered genes during development. Biochem. Biophys. Res. Commun., 270, 458-461.

79) Miura, N. and Naganuma, A. (2000) Metallothionein mediates gene expression of $3.1 \mathrm{mRNA}$ (PTZ17) related to epileptic seizure. FEBS Lett., 479, 146-148.

80) Miura, N. and Koizumi, S. (2005) Gene expression profiles in the liver and kidney of metallothioneinnull mice. Biochem. Biophys. Res. Commun., 332, 949-955.

81) Itoh, N., Shibayama, H., Kanekiyo, M., Namphung, D., Nakanishi, T., Matsuyama, A., Odani, T. and Tanaka, K. (2005) Reduced bactericidal activity and nitric oxide production in metallothioneindeficient macrophages in response to lipopolysaccharide stimulation. Toxicology, 216, 188-196.

82) Salom, M. G., Arregui, B., Carbonell, L. F., Ruiz, F., Gonzalez-Mora, J. L. and Fenoy, F. J. (2005) Renal ischemia induces an increase in nitric oxide levels from tissue stores. Am. J. Physiol. Regul. Integr. Comp. Physiol., 289, R1459-R1466.

83) Aravindakumar, C. T., Ceulemans, J. and De Ley, M. (1999) Nitric oxide induces $\mathrm{Zn} 2+$ release from metallothionein by destroying zinc-sulphur clusters 
without concomitant formation of S-nitrosothiol. Biochem. J., 344, 253-258.

84) Gow, A. and Ischiropoulos, H. (2002) NO running on MT: regulation of zinc homeostasis by interaction of nitric oxide with metallothionein. Am. J. Physiol. Lung Cell. Mol. Physiol., 282, L183-L184.

85) Haase, H. and Maret, W. (2003) Intracellular zinc fluctuations modulate protein tyrosine phosphatase activity in insulin/insulin-like growth factor-1 signaling. Exp. Cell Res., 291, 289-298.

86) Bruinsma, J. J., Jirakulaporn, T., Muslin, A. J. and Kornfeld, K. (2002) Zinc ions and cation diffusion facilitator proteins regulate Ras-mediated signaling. Dev. Cell, 2, 567-578.

87) Jirakulaporn, T. and Muslin, A. J. (2004) Cation diffusion facilitator proteins modulate Raf-1 activity. $J$. Biol. Chem., 279, 27807-27815.

88) Kimura, T., Itoh, N., Sone, T., Tanaka, K. and Isobe, M. (2004) C-terminal deletion mutant of MREbinding transcription factor-1 inhibits MRE-driven gene expression. J. Cell. Biochem., 93, 609-618.

89) Kimura, T., Itoh, N., Sone, T., Kondoh, M., Tanaka, K. and Isobe, M. (2006) Role of metal-responsive transcription factor-1 (MTF-1) in EGF-dependent DNA synthesis in primary hepatocytes. J. Cell. Biochem., 99, 485-494.

90) Kimura, T., Itoh, N., Takehara, M., Oguro, I., Ishizaki, J., Nakanishi, T., Isobe, M. and Tanaka, K. (2003) Protective effect of zinc against lipopolysaccharide/D-galactosamine-induced lethality. J. Health Sci., 49, 40-44.

91) Cherian, M. G., Jayasurya, A. and Bay, B. H. (2003) Metallothioneins in human tumors and potential roles in carcinogenesis. Mutat. Res., 533, 201-209.

92) Yamasaki, S., Sakata-Sogawa, K., Hasegawa, A., Suzuki, T., Kabu, K., Sato, E., Kurosaki, T., Yamashita, S., Tokunaga, M., Nishida, K. and Hirano, T. (2007) Zinc is a novel intracellular second messenger. J. Cell Biol., 177, 637-645. 